\title{
AMBiguity AND THE AMENDMENTS TO THE ALBERTA LAND STEWARDSHIP ACT
}

\author{
MARIA LAVELLE*
}

Recent amendments to the Alberta Land Stewardship Act (ALSA) are ambiguous, and the amended Act risks being interpreted in such a way as to undermine the purpose of Alberta's Land-use Framework (LUF) and result in more land use planning controversy. The LUF is intended to ensure the future economic growth of the province balanced with the achievement of societal and environmental goods. The LUF can be understood as reflecting a modern liberal approach to land use planning such that government regulation is applied to all property, whether publicly or privately owned. This article argues that the resulting amendments are ambiguous and could be interpreted as reflecting a different understanding of property rights rooted in classical liberalism. The result is that the amended ALSA might not be interpreted in such a way that furthers the goals of the LUF. This article suggests that if the legislation is intended to implement the LUF, then any amendments to the ALSA should be unambiguously consistent with the underlying values of the LUF. It also suggests areas where the processes under the Act could be made more open and transparent so as to be more coherent with modern liberalism.
Les récents amendements à la loi albertaine sur l'aménagement du territoire agricole (Alberta Land Stewardship Act (ALSA)) ont ambigus et la Loi amendée risque d'être interprétée de manière à saper la raison d'être de la politique-cadre sur l'aménagement du territoire de l'Alberta (Land-use Framework (LUF)) et entraîner une plus grande controverse quant à la planification de l'aménagement $d u$ territoire. La LUF a pour but d'assurer la croissance économique de la province de pair avec la réalisation de biens sociétaux et environnementaux. La LUF peut être vue comme le reflet d'une approche libérale moderne à la planification de l'aménagement du territoire en ce sens que la réglementation gouvernementale s'applique à toutes les propriétés, et ce qu'elles soient privées ou publiques. Cet article fait valoir le fait que les amendements qui en résultent sont ambigus et pourraient être interprétés comme étant le reflet d'une interprétation différente des droits de propriété enracinés dans le libéralisme classique. Il en résulte que la ALSA amendée ne peut pas être interprétée de manière à servir les objectifs de la LUF. L'article laisse croire que si la loi a pour but la mise en œuvre de la LUF, alors les amendements à la ALSA devraient se conformer sans équivoque aux valeurs fondamentales de la LUF. L'article précise aussi des secteurs où les processus en vertu de la Loi pourraient être plus ouverts et de manière à être cohérente avec le libéralisme moderne.

\section{TABLE OF CONTENTS}

I. InTRODUCTION . . . . . . . . . . . . . . . . . . . . . . 580

II. THE LAND-USE FRAMEWORK: UNDERLYING VALUES AND

SignificANCE AS A LAND USE MANAgEMENT StRATEgy . . . . . . . . . 582

A. THe LAND-USE FRAMEWORK'S PuRPOSE AND VALUeS . . . . . . . . 582

B. Land Use Management Strategy . . . . . . . . . . . . . 582

C. THE LAND-USE FRAMEWORK REFLECTS A MODERN LIBERAL APPROACH TO LAND UsE PLANNING . . . . . . . . . . . . 583

III. THE ALBERTA LAND STEWARDSHIP ACT AND THE PROPERTY RIGHTS CONCERNS OF LANDOWNERS $\ldots \ldots \ldots \ldots \ldots \ldots \ldots \ldots \ldots \ldots$

Counsel, Alberta Law Reform Institute. All views expressed in this article are those of the author and do not necessarily represent the views of, and should not be attributed to, the Alberta Law Reform Institute. Thank you to Professors Alistair Lucas and Nigel Bankes for their comments on an earlier draft. Special thanks to Professor Gregory Hagen for his encouragement and his comments on an earlier draft. An earlier version of this article was submitted as part of the course requirements for the University of Calgary's Faculty of Law Graduate Certificate Program. 
A. The ALBERTA LAND SteWARDSHIP ACT IN BRIEF . . . . . . . . . 586

B. LANDOWNER CONCERNS ABOUT THE

ALBERTA LAND STEWARDSHIP ACT . . . . . . . . . . . . . . . . 586

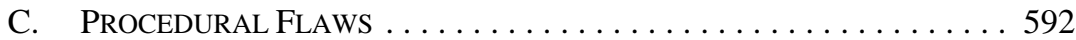

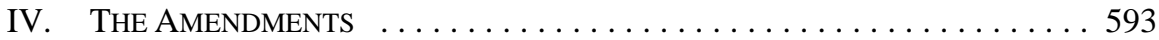

A. Amendment to the Purposes SEction . . . . . . . . . . . . . . . . . 594

B. AMENDMENTS TO THE DEFINITION OF

“STATUTORY CONSENT” AND SECTION $11 \ldots \ldots$. . . . . . . . . 595

C. AMENDMENT TO SECTION 19 (COMPENSATION) AND THE

ADDITION OF SECTION 19.1 (RIGHT TO COMPENSATION

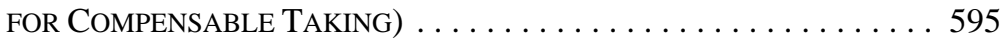

D. A New Variance Procedure in Section $15.1 \ldots \ldots \ldots \ldots$. . . . . . 597

E. A New Review Procedure in SEction 19.2 . . . . . . . . . . . . . . 598

F. IMPACT OF AMENDMENTS ON THE DISCRETIONARY

REgionAL PlanNing PROCESS . . . . . . . . . . . . . . . . 599

V. THE WAY FORWARD . . . . . . . . . . . . . . . . . . . . . . . . . . . 599

VI. CONCLUSION ............................600

\section{INTRODUCTION}

In recognition of the mounting industrial, residential, and community pressure on its land base, the Government of Alberta introduced its plan for a new land use policy, the Land-use Framework (LUF), in 2008. ${ }^{1}$ The $L U F$ provides for provincial government direction over land use across the province. The stated purpose of the $L U F$ "is to manage growth, not stop it ... to sustain [Alberta's] growing economy, but balance this with Albertans' social and environmental goals."2

In 2009, the Alberta Land Stewardship Act, the primary legislation which implements the $L U F$, came into force. ${ }^{3}$ The $A L S A$ was quickly subject to criticism by some private landowner groups who viewed it as a threat to their private property rights. ${ }^{4}$

The Alberta Land Stewardship Amendment Act, 2011 (the Amendments) ${ }^{5}$ was introduced by the Alberta government in response to these criticisms. The Government of Alberta denied that the ALSA threatened property rights. ${ }^{6}$ The government introduced the Amendments to clarify the ALSA. This article will demonstrate, however, that rather than clarifying the meaning of key provisions in the ALSA, the Amendments - particularly the new provision regarding respect for private property in the purpose section and the additional

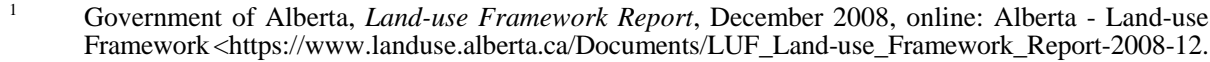
pdf $>[L U F]$.

Ibid at 6.

SA 2009, с A-26.8 [ALSA].

See e.g. Don Patterson, "Critics argue legislation threatens property rights" St. Albert Gazette (26 January 2011), online: St Albert Gazette <http://www.landownersagainstbills.com/articlesandeditorials. htm>; Lorne Gunter, “Land bills an attack on everyone’s freedom” Edmonton Journal (13 March 2011), online: Canada.com <http://www2.canada.com/edmontonjournal/columnists/story.html? id=26280a34eca2-4993-a4f0-4d763dbc1d45>.

SA 2011, c 9, amending SA 2009, с A-26.8 [ALSA Amendment].

Alberta, Legislative Assembly, Alberta Hansard, 27th Leg, 4th Sess, (8 March 2011) at 247 (Hon Kenneth R Kowalski). 
provision regarding a right to compensation — add a layer of ambiguity. This ambiguity, coupled with new legislative provisions in the Amendments that provide processes for landowners to challenge regional plans, and compounded by weaknesses in the regional planning processes of the original act, could undermine the ability of the ALSA, as amended, to satisfy the purpose of the $L U F$.

This article argues that this legislative ambiguity is rooted in differing theories of liberalism — modern and classical — that may be understood as being simultaneously reflected in the approaches to land use regulation embodied in the legislation. It does not pass judgement on either theory, nor does it purport to provide a comprehensive description of each theory. Rather, it describes these two political theories as a way to explain and understand the competing approaches to land use regulation that are taken by the legislature and some landowners.

Both the $L U F$ and the $A L S A$ can be understood as reflecting, primarily, a modern liberal approach to land regulation. As will be discussed later, the modern liberal approach to land regulation supports government regulation of lands in order to increase public goods, such as clean water, clean air, and biodiversity. ${ }^{7}$ On such a view, government planning (as opposed to private planning) to ensure the provision of public goods is justified because of the normative priority of legitimate government decision-making about land use over individual, private decision-making and private ownership of land. ${ }^{8}$ To put it differently, rights of landowners in their land do not exist apart from the decisions of government to create or to maintain such rights.

At the same time, the landowner criticisms of the ALSA reflect more of a classical liberal approach to the ownership and regulation of land. On a classical liberal view, property rights in land arise independently of decisions of a government. Classical liberals do not oppose government intervention where private intervention cannot provide necessary public goods (such as defence) and where there is no free-riding on the benefits. ${ }^{9}$ However, classical liberals tend to oppose land use regulation in order to provide public goods because, in their view, the costs tend to fall disproportionately on the affected landowners rather than proportionately on everyone who benefits. ${ }^{10}$

The problem is that, while the $L U F$ and $A L S A$ primarily reflect a modern liberal approach to land regulation and ownership, the Amendments were designed to address the criticisms of the landowners groups, whose views reflect a classical liberal approach. Some of the key Amendments are ambiguous and might be interpreted in accordance with a classical liberal approach to give a higher priority to private ownership of lands than did the ALSA and the $L U F$. As will be discussed later, the Amendments also create additional variance and review procedures that are focused on the private property owner to the exclusion of other interested parties. The result is that, if interpreted in accordance with a classical liberal approach, the

N Scott Arnold, Imposing Values: An Essay on Liberalism and Regulation (New York: Oxford University Press, 2009) at 22-28.

Ibid at 329.

Ibid at 25.

Ibid at 337. 
ALSA, as amended, could move farther from implementing the intended purpose and values underlying the $L U F$ than the original legislation.

This article will first explore the purpose and values underlying the LUF and demonstrate that it reflects a modern liberal approach to land use regulation. It also looks at the LUF's significance as a land use management strategy for the province. It will then provide a brief overview of the ALSA, showing how it implements the LUF. It then explains why the concerns of private landowners about the ALSA are ideologically motivated — reflecting classical liberal values — rather than being legally well-founded. It then analyzes the principal Amendments, arguing that they introduce ambiguities which could undermine the purpose of the LUF. Finally, it suggests a direction that the Amendments should take so as to result in legislation that would support and implement Alberta's LUF.

\section{THE LAND-USE FRAMEWORK: UNDERLYING VALUES AND SIGNIFICANCE AS A LAND USE MANAGEMENT STRATEGY}

\section{A. The LAND-USE Framework's Purpose AND VALUES}

The LUF is a government blueprint for a new land use policy for Alberta: "The Land-use Framework sets out an approach to manage public and private lands and natural resources to achieve Alberta's long-term economic, environmental and social goals." ${ }^{\text {"11 }}$ At the same time, the LUF expressly states that it is "[r]espectful of private property."

The strategy of the $L U F$ is to divide the province into seven regional areas defined by seven major watersheds. ${ }^{13}$ Regional plans for land use will then be approved by the provincial Cabinet for each of these regions. ${ }^{14}$ Under the $L U F$, regional plans will apply to both public and private lands. ${ }^{15}$ Municipal governments and provincial departments will be required to comply with these regional plans in their decision-making. ${ }^{16}$ A central rationale for the $L U F$ is that it provides public goods, such as clean water, air, and protects biodiversity. The LUF acknowledges that "[c]lean water and air, healthy habitat and riparian areas, abundant wild species and fisheries are all 'public goods' that Albertans enjoy and value." ${ }^{17}$ It also observes that much of the habitat and wetlands on private lands have disappeared because the cost of providing these public goods would have to be borne by individual ranchers and farmers, who have not done so. ${ }^{18}$

\section{B. LAND USE MANAGEMENT STRATEgY}

In terms of a land use management strategy, the LUF represents a significant departure from previous land use management strategies in the province that have focused on a

LUF, supra note 1 at 7 .

Ibid at 16.

Ibid at 20.

Ibid.

Ibid at 7.

Ibid at 19 .

Ibid at 20

Ibid. 
"multiple use" approach. ${ }^{19}$ "Multiple use is based on the premise that public lands have a variety of values and can simultaneously meet the needs of many users. The objective is to encourage complementary uses and balance competing uses in order to maximize aggregate benefits." 20 The LUF notes that the current multiple use approach to land management "is based on project-by-project approval and mitigation of the adverse effects of each project." 21 Importantly, it observes that while this approach may have been acceptable for low levels of development, it does not adequately respond to either the cumulative effects or the current pace of development in the province. ${ }^{22}$

The LUF represents a move towards an ecosystem management approach to land management and away from a multiple use approach. An ecosystem management approach refers to "a set of normative principles and operational guidelines for managing human activities in a way that permits them to coexist, over a specified management area, with ecological processes deemed to be worth protecting over the long term." ${ }^{23}$ In so doing, an ecosystem management approach recognizes the environmental public goods arising from these ecological processes. Rather than considering land use management from the user's perspective on project-by-project basis, the LUF considers the cumulative effect of development on the ecosystem in seven regional areas of the province defined by seven major watersheds in the province over the long-term. ${ }^{24}$

Further, whereas other land use management strategies have been primarily at the local level leading to a patchwork of development strategies across the province, ${ }^{25}$ the $L U F$ is focused on providing an overall provincial direction to planning at regional and local levels. ${ }^{26}$ Also, as discussed above, the LUF applies to both private and public lands, rather than previous efforts which saw separate strategies for public and private lands. ${ }^{27}$ As will be discussed further in the next section, the $L U F$ is a comprehensive planning document implemented by legislation, including the $A L S A$, which requires that other government departments and local governments comply with regional plans. ${ }^{28}$

\section{THE LAND-USE FRAMEWORK REFLECTS A MODERN Liberal Approach to LAND USE PlanNing}

The $L U F$ can be explained as generally reflecting a modern liberal approach to land use regulation because of the active and comprehensive role that the government takes to regulate both public and private lands in its territory. For modern liberals, ownership of land

Steven A Kennett, “New Directions for Public Land Law” (1998), CIRL Occasional Paper \#4, Canadian Institute of Resources Law at 10, online: University of Calgary Institutional Repository <http://dspace. ucalgary.ca/bitstream/1880/47208/1/OP04Directions.pdf $>$.

Ibid. Kennett elaborates on the three main criticisms of the multiple use approach at 11-14. First, multiple use confers "largely unfettered discretion" on public land managers (ibid at 11). Second, "it fails to provide the normative basis for decision-making” (ibid at 12). Third, the practical effect of this approach is that it "tilt[s] the playing field in favour of certain types of interests and values" (ibid at 13). Supra note 1 at 31.

Ibid.

Kennett, supra note 19 at vi.

LUF, supra note 1 at 31 . "Cumulative effects denotes the combined impact of past, present and reasonably foreseeable human activities on a region's environmental objectives.”

Frederick Laux, Planning Law and Practice in Alberta, 3d ed (Edmonton: Juriliber, 2002) at 1-5. Supra note 1 at 26.

Ibid at 16 .

ALSA, supra note 3 , ss 20-21. 
is an outcome of governmental policy on land ownership. ${ }^{29}$ The $L U F$ contemplates that regional plans developed by Cabinet will define land use activities on both private and public lands in each of the seven regions in the province. ${ }^{30}$ Professor Scott Arnold describes the implications of a modern liberal approach to land use regulation as follows:

[M]odern liberals believe that the state has some sort of priority of ownership of what is otherwise private property. In consequence, land use regulation can be justified as the exercise of the state's (or perhaps society's) ownership rights in productive assets — at least so long as the state does not usurp too many of the rights and privileges of ownership (so that ownership is private in name only) and so long as the process from which such regulations emerge is tolerably open and democratic. ${ }^{31}$

Modern liberals favour state intervention to ensure the provision of public goods. ${ }^{32}$ Public goods are usually defined to be those goods that are "nonexcludable" and "nonrivalrous."33 Given this definition, it is usually argued that state production of public goods is needed in order to prevent the failure of the private market to produce such goods. Since, if a good owned by one person can be consumed by another person without cost and it is impossible to prevent that from happening, then such free-riders prevent the market production of public goods. $^{34}$

In the $L U F$, the Alberta government used this "market failure argument" to justify government intervention to provide environmental public goods:

\footnotetext{
Clean water and air, healthy habitat and riparian areas, abundant wild species and fisheries are all "public goods" that Albertans enjoy and value. The costs of supplying these goods on private lands are left largely on the shoulders — and pocketbooks — of our ranchers and farmers. ${ }^{35}$
}

This explains why much habitat and wetlands have disappeared in recent decades and why there has been an increase in the conversion of agricultural lands to other uses. ${ }^{36}$

Under the $L U F$, the Alberta government contemplates providing public goods by using a range of tools including expropriation, conservation easements, and tax incentives. The resulting effect on the private property rights of landowners has the potential to directly clash with the classical liberal understanding of private property rights.

Arnold, supra note 7 at 329.

Supra note 1 at 3.

Supra note 7 at 329.

Ibid at 25.

Conventionally, public goods theory is thought to begin with Paul A Samuelson, "The Pure Theory of Public Expenditure" (1954) 36:4 The Review of Economics and Statistics 387. Arnold, supra note 7 at 22 described "nonrivalrous" as the fact that, once created, a public good can be consumed at no marginal cost. "Nonexcludable" refers to the practical inability to exclude people from consumption of the good. John Rawls discusses public goods from a modern liberal approach in John Rawls, A Theory of Justice (Cambridge, MA: Harvard University Press, 1971) at 266-70.

34 See generally Russell Hardin, “The Free Rider Problem” The Stanford Encyclopedia of Philosophy (Spring 2008), online: Stanford Encyclopedia of Philosophy <http://plato.stanford.edu/archives/ spr2008/entries/free-rider/>.

$35 \quad$ Supra note 1 at 3.

Ibid at 20. 
For the classical liberal, ownership of productive assets lies in the first instance, not with the state, but with private parties. ${ }^{37}$ This is because liberty and private property are "intimately related," 38 such that "all rights, including liberty rights, are forms of property."39 From a classical liberal perspective, an individual is entitled to their property holdings through a just acquisition, or a just transfer from a just acquisition. ${ }^{40}$

Classical liberals generally prefer non-state solutions to the provision of public goods. ${ }^{41}$ There are, however, some public goods, such as national defence and criminal justice, that both modern and classical liberals agree should be provided by the state. ${ }^{42}$ For the classical liberal, key conditions to accept state provision of a public good include: (i) that the individual benefits must be greater than the individual costs, at least for the vast majority; and (ii) the costs must be shared amongst those individuals who benefit. ${ }^{43}$ Government regulation of private land in order to create a public good may meet condition (i), in that for the vast majority of individuals the benefits outweigh the costs, even if this is not the case for a few individual landowners. The problem, however, lies with meeting condition (ii), in that the cost is disproportionately paid for by the affected landowners. ${ }^{44}$ Under the classical liberal view, state provision of a public good in these circumstances would be defensible only if the government compensated the affected landowners for the diminished value of the land and the landowners were only required to contribute a share of the cost. ${ }^{45}$

The dispute could be reframed in terms of differing views about the public interest. For the modern liberal, there is a sense in which a government act can be in the public interest without it being in each individual's interest. John Rawls defined this public interest or common good as “certain general conditions that are ... equally to everyone's advantage."46 For instance, a just tax will not benefit individual earners of the highest incomes. However, it is in the public interest or equally to everyone's advantage, to live in a society with a just distribution of wealth. Similarly, conservation of a particular wetland on private property may come at a net cost to a private landowner, but it may nonetheless be in the public interest to live in a society with a just distribution of environmental goods.

For classical liberals, however, the public interest refers to "the good of every particular member of that society." ${ }^{47}$ On this reading, where government land use regulation affects

Arnold, supra note 7 at 329.

Gerald Gaus \& Shane D Courtland, "Liberalism” The Stanford Encyclopedia of Philosophy (Spring 2011) at 7, online: The Stanford Encyclopedia of Philosophy <http://plato.stanford.edu/archives/ spr2011/entries/liberalism/>.

Ibid.

Robert Nozick, Anarchy, State, and Utopia (New York: Basic Books, 1974) at 151, cited in Julian Lamont \& Christi Favor, "Distributive Justice” The Stanford Encyclopedia of Philosophy (Spring 2009) at 21, online: The Stanford Encyclopedia of Philosophy <http://plato.stanford.edu/archives/spr2009/ entries/justice-distributive/>.

Arnold, supra note 7 at 25.

Ibid at 22-23. Arnold provides that the rationale for state provision of these public goods as follows: "There are some public goods people would prefer having to not having at a certain price, but they are so costly that no one's contribution would be sufficient to pay for the good and indeed would be negligible relative to the total cost of the good. In the absence of compulsory contribution, ...no one contributes, and the good does not get provided, even though it is worth the cost for each person.” Ibid at 178 .

Ibid.

Ibid.

Supra note 33 at 246.

John Locke, Two Treatises of Government (Hamilton: McMaster University Archive of the History of Economic Thought, 2000) at 62. 
individual landowners negatively or not as beneficially as other individuals, it is against the public interest.

III. THE ALBERTA LAND STEWARDSHIP ACT AND THE PROPERTY RIGHTS CONCERNS OF LANDOWNERS

\section{A. The Alberta LAND STEWARDSHIP ACT IN BRIEF}

The ALSA is enabling legislation that implements the $L U F{ }^{48}$ The purposes of the Act reflect the underlying objectives of the $L U F{ }^{49}$ The $A L S A$ establishes an integrated regional planning system. ${ }^{50}$ It also provides that regional plans are binding and sets up a compliance mechanism. ${ }^{51}$ Like the $L U F$, the $A L S A$ establishes a range of conservation and stewardship tools to encourage land stewardship on private land. ${ }^{52}$ In addition, it creates a new governance structure to facilitate an integrated regional planning process and its administration. ${ }^{53}$ By imposing a comprehensive framework for government land use regulation on both public and private lands in the province without compensation for every loss of value to landowners, the $A L S A$ takes a modern liberal approach to land use regulation.

\section{B. LANDOWNER CONCERNS ABOUT THE ALBERTA LAND STEWARDSHIP ACT}

As discussed earlier, the ALSA has motivated concerns amongst some landowners and others who view the legislation as an attack on private property rights. The government has claimed that "there have been some, probably deliberate, interpretations of the original act that were never intended. ${ }^{54}$ Whether, as the government suggests, those interpretations were deliberate or not, these misinterpretations of the ALSA could result from a difference in political views. Indeed, while the landowners' concerns are often framed as legal arguments, at root, they are better understood as being motivated by a difference in political values.

The main legal claims made by landowner groups in regards to how property rights are weakened under ALSA can be summarized as follows:

A detailed review of the ALSA is beyond the scope of this article. For a detailed review of the $A L S A$, see e.g. Cindy Chiasson, Jason Unger \& Jody Hierlmeier, "Comments on Bill 36, the Alberta Land Stewardship Act” (2009), Environmental Law Centre, online: Environmental Law Centre <http://www. elc.ab.ca/content_Files/Files/BriefsAndSubmissions/CommentsonBill36May2009.pdf>; Alan Harvie \& Trent Mercier, “The Alberta Land Stewardship Act and its Impact on Alberta's Oil and Gas Industry” (2010) 48:2 Alta L Rev 295.

49 Supra note 3. Section 1(2) of the Act provides that the purposes are:

(a) to provide a means by which the Government can give direction and provide leadership in identifying the objectives of the Province of Alberta, including economic, environmental and social objectives;

(b) to provide a means to plan for the future, recognizing the need to manage activity to meet the reasonably foreseeable needs of current and future generations of Albertans, including aboriginal peoples;

(c) to provide for the co-ordination of decisions by decision-makers concerning land, species, human settlement, natural resources and the environment;

(d) to create legislation and policy that enable sustainable development by taking account of and responding to the cumulative effect of human endeavour and other events.

Ibid, ss 3-12.

Ibid, ss 13-22.

Ibid, ss 23-50.

Ibid, ss 51-67.

Alberta Hansard, supra note 6 at 247. 
1. The ALSA allows Cabinet to amend or “extinguish” land title without applying the procedural and substantive protections of the Expropriation Act. ${ }^{55}$

2. It restricts the right to compensation where existing rights are amended or extinguished.

3. It provides there is no appeal to the courts and includes a privative clause blocking a citizen's right to seek judicial review or commence an action. ${ }^{56}$

The following sections examine each of these legal claims and explain why they are not legally well-founded.

\section{THE ALBERTA LAND STEWARDSHIP ACT EXTINGUISHES}

\section{LAND TITLE WiTHOUT PROCEDURAL AND SUBSTANTIVE SAFEGUARDS}

Critics of the ALSA contend that it would permit the government to extinguish land title without the procedural and substantive safeguards found in the Expropriation Act. The argument centers on section 11(1) of the ALSA which provides:

For the purpose of achieving or maintaining an objective or a policy of a regional plan, a regional plan may, by express reference to a statutory consent or type or class of statutory consent, affect, amend or rescind the statutory consent or the terms or conditions of the statutory consent. ${ }^{57}$

"Statutory consent” is broadly defined in the ALSA as: "a permit, licence, registration, approval, authorization, disposition, certificate, allocation, agreement or instrument issued under or authorized by an enactment or regulatory instrument." 58 While "land title" is not included in this list, critics assert that because "instrument" is defined in the Land Titles Act t9 $^{59}$ to include a certificate of title, then the reference to "instrument" in the definition of "statutory consent" in the ALSA includes land title and, therefore, a regional plan can extinguish land title as well. ${ }^{60}$

This assertion is not legally well-founded for the reasons ably expounded by Nigel Bankes in a blog post and summarized here.$^{61}$ First, the ordinary meaning of a "statutory consent" is that it is "an authorization to do something that would otherwise be prohibited by statute." Accordingly, a certificate of title would not be included in the ordinary meaning of "statutory consent." Second, the definition of "statutory consent" in the ALSA does not expressly include land title. And finally, section 9 of the ALSA contemplates that a regional plan could

RSA 2000, c E-13.

Keith Wilson, "Impacts of New Provincial Legislation and Recent Case Law Developments on Landowner Rights and Compensation,” (Paper delivered at the Legal Education Society of Alberta Conference, 13 November 2009) at 11, [unpublished], online: Canadian Association of Energy and Pipeline Landowner Associations <http://www.landownerassociation.ca/rsrcs/Wilsoncritique.pdf>.

Supra note 3, s 11(1).

Ibid, s 2(aa) [emphasis added].

RSA 2000, c L-4, s 1(k).

Wilson, supra note 56 at 12 .

Nigel Bankes, "ALSA and the property rights debate in Alberta: a certificate of title to land is not a 'statutory consent,' ABlawg.ca (11 February 2011), online: ABlawg.ca <http://ablawg.ca/2011/02/11/ alsa-and-the-property-rights-debate-in-alberta-a-certificate-of-title-to-land-is-not-a-"statutory-consent” $>$. 
trigger the Expropriation $A c t ;{ }^{62}$ it is therefore unreasonable to interpret section 11 as providing an additional and alternative means of effecting expropriation.

\section{THE ALBERTA LAND STEWARDSHIP ACT RESTRICTS THE RIGHT TO COMPENSATION}

Critics assert that the ALSA effectively "restricts rights to compensation where existing rights are amended or extinguished." 63 This argument is not legally well-founded, as the ALSA creates a new statutory right to compensation for conservation directives that supplement subsisting rights to compensation under other statutes and at common law.

It is unfortunate that the primary provision dealing with a right to compensation under the ALSA, section 19, was written in the negative as that only fed critics' concerns. Section 19, entitled "Compensation limited," provided that "no person" has a right to compensation by reason of the $A L S A$, a regulation under the $A L S A$, or a regional plan, except as provided in Part 3, Division 3 (Conservation Directives), or as provided for under another enactment. ${ }^{64}$ Critics appear to read this provision as unduly restricting any right to claim compensation. ${ }^{65}$ For the reasons that follow this is not a reasonable legal interpretation of this provision.

Those who view section 19 as limiting the right to compensation are motivated in part by a misinterpretation of section 11 of the $A L S A$ that would, for example, permit land title to be extinguished without compensation. As discussed in the preceding section, this does not appear to have ever been the intention of the ALSA. Further, where land has been expropriated by the government there is a presumption in favour of compensation. ${ }^{66}$ The often-cited common law rule is that stated by Lord Atkinson in Attorney-General $v$ De Keyser's Royal Hotel Ltd: "[U]nless the words of the statute clearly so demand, a statute is not to be construed so as to take away the property of a subject without compensation." ${ }^{67}$ The ALSA makes no such statement that property can be expropriated without compensation. Rather, section 19 provides that there may be a right to compensation as a result of the ALSA, its regulations, or a regional plan. ${ }^{68}$

In addition, there may be a misperception by critics of the ALSA that existing rights to compensation under either statute or common law are broader than they actually are. Where the property was taken pursuant to a statutory authority, a right to compensation would be available under statute for direct expropriation. ${ }^{69}$ A statute might also provide a right to claim

\section{$62 \quad$ Wilson, supra note 56 at 11.}

$63 \quad$ Ibid at 11.

$64 \quad$ Harvie \& Mercier, supra note 48 at 322, note that reference to “person” in section 19 of ALSA rather than "title holder" expressly expands the right to compensation to any person rather than just those who fit within the narrow definition of a "title holder" contained in the Act.

65 Wilson, supra note 56 at 16.

66 Eric CE Todd, The Law of Expropriation and Compensation in Canada, 2d ed (Toronto: Carswell, 1992) at 35.

[1920] AC 508 (HL) at 542.

Harvie \& Mercier, supra note 48 at 322.

Section 9(2)(h) of the ALSA, supra note 3, contemplates that a regional plan may "authorize expropriation by the Crown under the Expropriation Act." The Expropriation Act, supra note 55, s 42(2), provides for compensation for expropriated land based on the market value of the land, damages for disturbances to the land, injurious affection, and any special economic advantage to the landowner arising out of or incidental to its occupation of the land. 
damages where property rights were affected (as defined by the statute) by an exercise of statutory authority. ${ }^{70}$ At common law, not every exercise of a statutory authority that affects a private property interest would give rise to a right to compensation. There would be a right to claim compensation only where the necessary conditions for an indirect expropriation are met. A regional plan would have to severely impair a property holder's interest before there would likely be a right to claim damages for indirect expropriation. ${ }^{71}$

Not only does section 19 not extinguish existing rights to compensation, it also creates a new statutory right to compensation. Part 3, Division 3 (sections 36-44) of the ALSA creates a new statutory right to compensation for Conservation Directives. Section 36 provides that a "title holder whose estate or interest in land is the subject of a conservation directive has a right to apply for compensation in accordance with this Division."72 Conservation Directives must expressly be declared in a regional plan and "may permanently protect, conserve, manage and enhance environmental, natural scenic, esthetic or agricultural values." ${ }^{73}$ A title holder whose interest in land is made subject to a Conservation Directive is entitled to compensation for the amount of the decrease in market value of the estate or interest in land, damages for injurious affection, and damages for any other loss specified in the regulations. A Compensation Directive could include, for example, a provision in a plan which prevents an owner from draining a wetland or developing part of their property in order to preserve a natural habitat. While in some cases a Compensation Directive might meet the test for indirect expropriation, not all will. Extending a right of compensation to all Conservation Directives goes beyond the existing statutory and common law rights to compensation.

\section{The ALSA PROVIDES No APPEAL TO THE COURTS AND NO JUDICIAL REVIEW}

It is incorrect to say that the $A L S A$ provides for no appeal to the courts and no judicial review. The ALSA uses new appeal mechanisms created under the Public Lands and Forest

It would be possible to make a claim for compensation for damages resulting from a regional plan under another enactment. For example, a regional plan might require that aquatic life be protected in a specific body of water in one of the regions. Pursuant to section 4.1 of the Water Act, RSA 2000, c W-3, the Minister or Director must act in accordance with a particular regional plan. The Director could, therefore, pursuant to a regional plan, amend existing water licences under section 52(4) of the Water Act to protect the aquatic life and the water licence holder could make a claim for compensation under section 158 of the Water Act. Section 19 of the ALSA expressly recognizes that a person may have a right to compensation by reason of the $A L S A$, a regulation under the $A c t$, or a regional plan as provided under another enactment.

71 The two-part test for indirect expropriation at common law is not easy to meet. First, there must be an extinction of rights. Second, there must be an acquisition of those rights by the government. The threshold for the first requirement has consistently been held by the courts to be quite high. It was described by Justice Marceau in Alberta (Minister of Public Works, Supply and Services) v Nilsson, 1999 ABQB 440, 246 AR 201 at para 48, as a regulation that "is of sufficient severity to remove virtually all of the rights associated with the property holder's interest.” On the second requirement, there is some confusion in the law as to whether the test is met by the acquisition of a tangible proprietary interest by the government (Canadian Pacific Railway Co v Vancouver (City of), 2006 SCC 5, [2006] 1 SCR 227) or the intangible gain of some benefit ( $R v$ Tener, [1985] 1 SCR 533). A full discussion of indirect expropriation is beyond the scope of this article. For a critical analysis of recent case law, see Russell Brown, "The Constructive Taking at the Supreme Court of Canada: Once More, Without Feeling” (2007) 40:1 UBC L Rev 315.

72 ALSA, supra note 3, s 36. Harvie \& Mercier, supra note 48 at 321, discuss how the definition of "title holder" is restrictive in that it expressly excludes from its scope interests granted under the Mines and Minerals Act, RSA 2000, c M-17. 
Act, as well as existing appeal mechanisms under other acts. ${ }^{74}$ As for judicial review, while it is clear that the government has sought to limit the availability of judicial review, this is not the same as saying there is no judicial review. ${ }^{75}$ It should be noted, however, that while a government can limit the availability of judicial review, the extent to which the government has tried to do this in the ALSA is not consistent with the level of transparency normally associated with a modern liberal approach to property regulation.

A few additional comments are warranted regarding the availability of judicial review under the ALSA because, in presentations on the ALSA, the Alberta government has highlighted three mechanisms which the government says are intended to "protect” regional plans from court review:

[a.] Separating process from decision-making to prevent successful process challenges

[b.] Making Regional Plans legislative instruments which typically the Courts will not second-guess

[c.] Includ[ing] a privative clause to help stop contents of plans being grounds for legal action. ${ }^{76}$

Contrary to the impression generated by these comments, however, the ALSA has merely limited appeal and judicial review of $A L S A$, as amended, rather than eliminating it. Each of these mechanisms will be considered in turn.

a. Separating the Process from the Decision-making

Does Not Preclude Judicial Review

Under the ALSA, the process of regional planning is separated from the decision-making in the sense that the Land-use Secretariat is responsible for preparing or directing the preparation of the land use plan for consideration by Cabinet. ${ }^{77}$ The Cabinet then has the discretion to decide whether to make or amend a regional plan irrespective of the advice of the Secretariat. This separated structure would not, however, preclude judicial review of the Cabinet's decision. In a recent Federal Court case, Justice Hughes confirmed that a Cabinet decision, like those of other government decision-makers, is properly the subject of judicial review. ${ }^{78}$

b. The Fact That Regional Plans are Legislative Instruments is Only

One Factor to Consider in Determining the Appropriate Standard of Review

Pursuant to section 13(2) of the ALSA, regional plans are legislative instruments under the $A L S A$ and for the purposes of any other Act are to be considered regulations. The

The ALSA included consequential amendments to a number of acts. Section 76 of the ALSA amended the Forests Act, RSA 2000, c F-22, and section 90 amended the Public Lands Act, RSA 2000, c P-40. See Dunsmuir v New Brunswick, 2008 SCC 9, [2008] 1 SCR 190 at para 52 [Dunsmuir].

76 Morris Seiferling, "The Alberta Land-use Framework Regional Planning and the Alberta Land Stewardship Act” (Presentation delivered at the Alberta Land Stewardship Act: A Practical \& Critical Colloquium, Faculty of Law, University of Calgary, 20 May 2010) at 19, online: University of Calgary Faculty of Law <http://www.law.ucalgary.ca/research/conferences/alsa>.

77 Supra note 3, s 58.

78 
significance of this for judicial review purposes is that courts have generally been deferential where a decision-maker is interpreting its own statute. ${ }^{79}$ However, this is only one of several factors that a court will consider in determining the appropriate standard of review.

\section{c. The ALSA Does Not Include a General Privative Clause}

There is much debate as to whether the privative clause in section 15(3) would preclude judicial review. ${ }^{80}$

\section{The relevant subsections of section 15 read as follows:}

Binding nature of regional plans

15(1) Except to the extent that a regional plan provides otherwise, a regional plan binds
(a) the Crown,
(b) local government bodies,
(c) decision-makers, and
(d) ... all other persons.

(3) Subject to subsection (5), subsection (1) does not
(a) create or provide any person with a cause of action or a right or ability to bring an application or proceeding in or before any court or in or before a decision-maker,
(b) create any claim exercisable by any person, or
(c) confer jurisdiction on any court or decision-maker to grant relief in respect of any claim.

(4) For the purposes of subsection (3), a claim includes any right, application, proceeding or request to a court for relief of any nature whatsoever and includes, without limitation,
(a) any cause of action in law or equity,
(b) any proceeding in the nature of certiorari, prohibition or mandamus, and
(c) any application for a stay, injunctive relief or declaratory relief.

(5) Subsection (3) does not apply in respect of an application by the stewardship commissioner to the Court of Queen's Bench under section 18.

The short answer is that section 15(3) is not written as a general privative clause. ${ }^{81}$ As a privative clause, it is limited to challenges to the binding nature of regional plans. As the

Dunsmuir, supra note 75 at para 54.

Wilson, supra note 56 at 14, describes section 15(3) as “a statutory bar against judicial review.” For the contrary view, see Bankes, supra note 61.

In response to comments on his ABlawg.ca article, Bankes, ibid, correctly argues that, were section 15(3) to be a general privative clause, it would have be written along the following lines: "No regional plan nor the application of that plan may be restrained by injunction, prohibition or other process or proceedings in any court, nor is a regional plan removable by certiorari or otherwise into any court" (16 February 2011). 
Alberta Court of Queen's Bench held in Keller v Municipal District of Bighorn No 8, section 15(3) should be read in conjunction with section 62 of the Act such that a person who wishes to bring a complaint regarding compliance with a regional plan must do so through the complaint process under the office of the Stewardship Commissioner. ${ }^{82}$ Section 15(3), however, would not prevent an application for judicial review from being brought by a person with standing in order to challenge the lawfulness of a regional plan. Accordingly, judicial review, albeit limited, is available.

As articulated, the opposition from landowner groups to the ALSA is not based on wellfounded legal concerns. Rather, they can better be explained and understood as reflecting a classical liberal approach to private property and land use regulation and accordingly, a challenge to the values and philosophy underpinning the LUF and the ALSA. Considering each of the landowner group's legal claims in turn, one can suggest they are motivated by a number of factors, including a preference for non-state solutions to public goods problems; the need for greater compensation to the landowner for any impact on property values resulting from government regulation to provide public goods; and a different conception of private property.

\section{Procedural Flaws}

While the criticisms of $A L S A$ are legally unfounded, that is not to say that the legislation is flawless. As noted by Professor Arnold, a modern liberal regulatory approach is characterized by the requirement of openness and transparency with respect to decisionmaking involving land use. ${ }^{83}$ However, while the $A L S A$ reflects generally a modern liberal approach to land regulation, it adopts a highly discretionary regional planning process with few checks and balances. For instance, much of the regional planning process under the ALSA is left entirely to Cabinet discretion. Cabinet has the discretion to "establish integrated planning regions." ${ }^{\prime 4}$ Cabinet also has the discretion to "make or amend regional plans" and may make regulations regarding all aspects of the amendment process. ${ }^{85}$ Cabinet may make or amend a regional plan without first establishing a regional advisory council (RAC) or considering the advice of either the RAC or the Land-use Secretariat. ${ }^{86}$ Cabinet may repeal a regional plan. ${ }^{87}$ In addition, a regional plan may contain provisions that Cabinet in its discretion considers necessary to advance or implement the purposes of the Act. ${ }^{88}$ Further, all aspects of the regional planning process and its administration are left to the discretion of Cabinet, including setting the terms of reference, the consultation requirements, and the roles and responsibilities of the RACs, government departments, and the Secretariat. ${ }^{89}$

Keller v Municipal District of Bighorn No 8, 2010 ABQB 362, 481 AR 93 at para 52.

Supra note 7 at 329.

ALSA, supra note $3, \mathrm{~s} 3$.

Ibid, ss 4(1)-4(2).

Ibid, s 51(2).

Ibid, s 6(4).

Ibid, s 9(1).

Ibid, s 51. The regional planning process not only violates the spirit of the modern liberal approach but the legal requirements of reasonableness under administrative law. The Supreme Court of Canada in Dunsmuir, supra note 75 at para 47, has held that reasonable regulatory decisions require "justification, transparency and intelligibility within the decision-making process" and that "the decision [must fall] within a range of possible, acceptable outcomes which are defensible in respect of the facts and law." 
Further, there is very little in the way of required content for the regional plans. Unlike a system where the essential elements are prescribed in the legislation or regulations, only two elements are required: a regional plan must "describe a vision for the planning region, and state one or more objectives for the planning region." ${ }^{90}$ Otherwise the rest of the contents of the regional plan are left to Cabinet's discretion.

Last, as discussed above, the extent to which the government has tried to limit access to judicial review is not consistent with the transparent procedural mechanisms that are essential to a modern liberal approach to land use regulation.

\section{THE AMENDMENTS}

The government responded to landowner concerns by introducing the Alberta Land Stewardship Amendment Act, 2011 on 1 March 2011. ${ }^{91}$ The Amendments were intended to clarify that the government respects all existing property rights and rights to compensation. ${ }^{92}$ The Amendments also instituted new checks and balances on government action in the form of a variance and review provision. ${ }^{93}$

The difficulty is that some of the Amendments — particularly the wording of the new provision regarding respect for property rights and the additional provision regarding a right to compensation - are ambiguous. This ambiguity, if interpreted in accordance with the classical liberal view and coupled with new processes for landowners to challenge regional plans, could result in weaker regional plans and have a chilling effect on regional planning. Further, these problems could be compounded by weaknesses in the regional planning process of the original $A L S A$, which could lead to misinterpretation and unprincipled decisions. As a result of all of this, an effective balance between competing economic, environmental, and social uses of land may not be achieved and the purposes of the LUF could be undermined.

The principal Amendments are as follows:

1. An express reference to respect for property rights is to be added to the purposes section.

2. The definition of "statutory consent" is to be refined, and section 11 of the ALSA is amended to make it clear that land title was never intended to be included as a statutory consent.

3. Section 19 is reframed in the positive, and the new section 19.1 regarding a right to compensation for compensable taking is added.

4. A new variance procedure is added by section 15.1 .

92 Government of Alberta, News Release, “Amended land use act addresses landowner concerns” (1 March 2011), online: Government of Alberta <http://www.gov.ab.ca/acn/201103/299867310A705-A560-E42738630BBB98E25D78.html>.

Ibid. 
5. A new review procedure is added by section $19.2 .{ }^{94}$

Each of these Amendments will be considered in turn to show the effect they might have on the implementation of the $L U F$.

\section{A. Amendment to the Purposes Section}

The Amendments add a new section 1(1) to the purposes section of the ALSA:

In carrying out the purposes of this Act... the Government must respect the property and other rights of individuals and must not infringe on those rights except with due process of law and to the extent necessary for the overall greater public interest. ${ }^{95}$

Thereafter section 1(2) continues the purposes listed under section 1 of original Act.

The addition of section 1(1) creates ambiguity as to the principles and values that inform the amended $A L S A .{ }^{96}$ The ambiguity results because, as discussed earlier, a classical liberal and a modern liberal will have different conceptions of what respect for property rights entails, and also what is necessary for the overall public interest. On a classical liberal approach, private property is to be given priority over public interests (in private land). Classical liberals would argue that the addition of this subsection signals that government is generally not to infringe on private property rights. Any infringement on private property rights would only be justified where it is in the public interest, defined as the good of every individual member of society.

On the other hand, those who subscribe to a more modern liberal approach would argue that the addition of this subsection does not alter the relative importance to be given to all of the purposes under the $A L S A$. That is to say, respect for private property rights merely recognizes the legal status quo.

Having a clear, unambiguous statement as to the purpose of the legislation is very important as the courts will draw upon the purposes section to assist in the interpretation of other provisions of the ALSA. Ambiguities in the purposes section are likely to lead to greater division amongst opposing interests and possibly more challenges to regional plans. If this amendment is interpreted in a way that is more consistent with the classical liberal approach to property regulation, then those responsible for regional plans might also be reticent to introduce changes that would impact on private property even where warranted by the overall public interest, and the purpose of the LUF could be undermined.

This Part uses the following ABlawg.ca article as a starting point for its organizational structure and analysis: Nigel Bankes, "Regulatory chill, weak regional plans, and lots of jobs for lawyers: the proposed amendments to the Alberta Land Stewardship Act,” ABlawg.ca (4 March 2011) online: ABlawg.ca <http:// ablawg.ca/2011/03/04/regulatory-chill-weak-regional-plans-and-lots-of-jobs-forlawyers-the-proposed-amendments-to-the-alberta-land-stewardship-act/>.

$95 \quad$ Supra note 5, s 2.

96 The purposes section of an act is generally understood as setting out the principles and philosophies that should inform the interpretation of the act as a whole: LeBlanc v LeBlanc, [1988] 1 SCR 217 at 221-22. 
There may also be questions as to the interpretation of other wording in this subsection, including the meaning of "infringe." The Alberta and federal Bill of Rights refer to the "deprivation" of property rights, rather than their infringement. ${ }^{97}$ What is the significance of an "infringement" as compared to a "deprivation"? Would any diminution of the market value of private property as a result of a regional plan amount to an “infringement”?

\section{B. AMENDMENTS TO THE DEFINITION OF “STATUTORY CONSENT" AND SECTION 11}

The amendments to section 11 are not necessary for the reasons given in Part III of this article. The Amendments, however, remove any doubt that section 11 was intended to mean that the government could extinguish legal title and bypass the procedural and substantive safeguards provided in the Expropriation Act. As the Minister of Sustainable Development, the Honourable Mel Knight, stated on second reading of the Bill: "Land titles ... were never included in the definition of statutory consent, and we've clarified that." ${ }^{\text {"98 }}$ The Amendments change the definition of "statutory consent" so that it expressly does not include any instrument issued under or authorized by the Land Titles Act. The definition similarly excludes any permit, licence, registration, approval, authorization, disposition, certificate, allocation, agreement, or instrument issued under or authorized by a list of other Acts. In case there was any lingering suspicion, the word "extinguish” in section 11 is struck out and replaced with "rescind." 99

\section{AmENDMENT to SECTiOn 19 (Compensation) AND the AdDition OF SECTION 19.1 (RIGHT TO COMPENSATION FOR COMPENSABLE TAKING)}

Section 19 of the ALSA is amended so that the right to compensation by reason of the $A L S A$, a regulation under the $A L S A$, or a regional plan is now worded in the positive (a person has a right to compensation) rather than framed in the negative (no person has a right to compensation). ${ }^{100}$ This change in tone does not appear to change the substance of the provision. ${ }^{101}$

The Amendments also add section 19.1, entitled a "Right to compensation for a compensable taking." "Compensable taking” is defined as "the diminution or abrogation of

Property rights are not constitutionally protected in Canada, but they are accorded quasi-constitutional protection in section 1(a) of the Alberta Bill of Rights, RSA 2000, c A-14 and section 1(a) of the Canadian Bill of Rights, SC 1960, c 44.

Alberta Hansard, supra note 6 at 248.

ALSA Amendment, supra note 5, s 8(a).

The new section 19, "Compensation," reads as follows:

A person has a right to compensation by reason of this Act, a regulation under this Act, a regional

plan or anything done under a regional plan

(a) as provided for under section 19.1,

(b) as provided for under Part 3, Division 3, or

(c) as provided for under another enactment.

101

Although here again, one could argue that in using positive language rather than negative language, in regards to compensation, the Legislature was signaling a move towards a more classical liberal theory of property regulation. 
a property right, title or interest giving rise to compensation in law or equity." ${ }^{\text {"102 }}$ In order to make a claim for a compensable taking a "registered owner" must demonstrate that there has been a compensable taking in respect of their private land or freehold minerals as a direct result of a regional plan or an amendment to a regional plan. ${ }^{103}$ Where a compensable taking is found, the amount of compensation is to be determined on the same basis as provided for private land or freehold minerals that were the subject of a Conservation Directive under Part 3, Division 3. ${ }^{104}$ The remaining subsections deal primarily with the process for making an application to a Compensation Board to determine if there has been a compensable taking and if so, the amount of compensation payable. Subsection 6 permits a registered owner to appeal a decision of the Compensation Board to the Court of Queen's Bench.

The ambiguity centres on the addition of section 19.1, which either creates a new statutory right to compensation, or simply confirms existing rights to compensation. Classical liberals might assert that it creates a new statutory right to compensation for any diminution in their property right, title or interest, including diminution in the value of the interest. ${ }^{105}$ This interpretation might be supported by the fact that the government created this provision in response to the demands of landowners. The classical liberals could point to the words "Right to compensation for compensable taking" in the title to the section 19.1 as creating a new statutory right. Further, they might point to the definition of "compensable taking" and assert that the term "diminution” creates a statutory right with a lower threshold than that of the current common law regarding indirect expropriation. ${ }^{106}$ A lower threshold, it could be said, exists, because the classical liberal view is that any diminution in the value of land by the government must be remedied through compensation.

At the same time, under the modern liberal approach, this provision simply confirms existing rights to compensation and creates a new appeal process for compensation. ${ }^{107}$ Those who support this view would point to the addition of the phrase "in law or equity" to the definition of "compensable taking" ${ }^{108}$ which suggests that the provision is meant only to include existing rights to compensation in either common law or equity.

Given this ambiguity, there is the possibility that this provision could be interpreted as creating a new statutory right to compensation. If this is the case, the threshold for making such a claim (a diminution of value) appears to be set low. The ambiguity of this provision raises the potential for a large number of compensation claims by registered owners who have experienced any lessening of (the market value of) their property right, title, or interest

Supra note 5, s 19.1(1)(a) [emphasis added]. The term, "compensable taking" is not one that is found in any other statute in Alberta or for that matter in Canada. It is a term that has been used infrequently in Canadian case law, but more commonly in the United States. The definition itself is somewhat circular in that a compensable taking is defined as something that gives rise to compensation in law or equity. Ibid, s 19.1(2).

Ibid, s 19.1(4).

"Diminution" is defined by Black's Law Dictionary, 7th ed, sub verbo "diminution" as the "act or process of decreasing, lessening, or taking away." A diminution of property interest, on this interpretation, implies a range of actions spanning anywhere from a near total loss of a property interest to a negligible lessening of the market value of the interest.

See Todd, supra note 65 at 22-23, for a brief discussion of the current common law threshold for indirect expropriation.

The Hon Mel Knight stated on second reading: "[W]e have also indicated that the right to all existing compensation and appeals to any other compensation issues are clearly stated." Alberta Hansard, supra note 6 at 248.

ALSA Amendment, supra note 5, s 19.1(1)(a). 
as a result of a regional plan. This uncertainty and the potential for a significant payout of compensation may have a chilling effect on regional planning, as drafters of the regional plans will not want to risk changes to the status quo.

\section{A New Variance Procedure in Section 15.1}

The Amendments also add a new variance procedure in section 15.1, which the title holder may access. The concern is that with the other amendments adding a layer of ambiguity to the amended $A L S A$, more frequent resort could be made to the variance procedure with the potential for a deluge of applications. This could result in weaker regional plans where numerous individual variances are granted. It could also have a chilling effect on regulatory planning, as drafters of regional plans may err on the side of making regional plans that are consistent with the status quo, rather than risk being inundated with variance requests.

Section 15.1(1) provides that a "title holder may to apply to the Stewardship Minister for a variance in respect of any restriction, limitation or requirement regarding a land area or subsisting land use, or both, under a regional plan as it affects the title holder." "Title holder" is defined so as to include registered owners, recorded estates or interests, and any other person in possession or occupation in the land. Section 15.1(2) provides three conditions that must be met before the Minister may grant a variance: (a) the variance must be consistent with the purposes of the $A L S A$; (b) "the proposed variance is not likely to diminish the spirit and intent of the regional plan"; and (c) "refusal to grant the proposed variance would result in unreasonable hardship to the applicant without an offsetting benefit to the overall public interest."

These conditions are of interest. ${ }^{109}$ The first two conditions, (a) and (b), are rather broad and are concerned with not having a proposed variance that is inconsistent with the purposes of the $A L S A$ or that would diminish the spirit and intent of the regional plan. Here again, the amendment to the purposes section could play a role in how an application for a variance is assessed.

The third condition, (c), requires a weighing of the hardship that would result from a refusal to grant a proposed variance with the benefit to the overall public interest if the variance is refused. Only where unreasonable hardship would result from the refusal to grant a variance without an offsetting benefit to the overall public interest may the Minister issue a variance. ${ }^{110}$ How these conditions are interpreted could be significantly impacted by the approach to property rights that underlies the amended $A L S A$.

If the amended $A L S A$ is interpreted as implementing a modern liberal approach to land use regulation, then the resulting advantage enjoyed by everyone would have to be weighed against the hardship to the individual landowner. Under this view, it would be relatively

They loosely track the conditions that are placed on a variance under sections 78(1)(a)-(c) of the Environmental Protection and Enhancement Act, RSA 2000, c E-12 [EPEA].

110 Section 78(1)(c) of the EPEA, ibid, permits the Minister to issue a variance certificate where "refusal to grant a certificate of variance would result in serious economic hardship to the applicant without an offsetting benefit to others." The courts have not considered this provision. The amendment to the ALSA appears broader than this provision of the EPEA as it is not limited to "serious economic hardship" but could extend to any "unreasonable hardship." 
difficult for a landowner to obtain a variance because it would be difficult to meet condition (c).

If, however, one were to interpret the amendments to the ALSA as indicating a shift towards a more classical liberal approach, then it is more difficult to imagine a scenario where the creation of a regulatory public good in private land would justify an unreasonable hardship to a private property owner. This is for two reasons. First, unreasonable hardship would include any government action affecting private land where the landowner is not compensated for the full market value of the diminished value of their land. Second, there would be no offsetting public interest as there would be no net benefit to the affected landowner.

There is very little in the way of the process for variance described in the ALSA. Instead, the Lieutenant Governor in Council may make regulations respecting the form and manner of making applications, application fees, rules regarding the granting, effect, and repeal of orders under this section, as well as respecting the manner in which applications and variances are to be made publicly available. ${ }^{111}$

\section{E. A New Review Procedure in Section 19.2}

The Amendments also add section 19.2 which permits a "person who is directly and adversely affected by a regional plan or an amendment” to request a review of the regional plan within a year of it coming into force. The requirement that a request for review be brought by a person who is directly and adversely affected could be interpreted as being more consistent with a classical liberal view of property as it is directed towards private property interests and not towards the public interest.

This provision is problematic in that there is no indication as to what the threshold for review is or what the results of a review could be. The request for a review is made to the Stewardship Minister who must then establish a panel to conduct the review. ${ }^{112}$ The panel reports the results of the review and any recommendations to the Minister, and these are then presented by the Minister to the Executive Council. ${ }^{113}$ Cabinet may make regulations concerning other procedural matters related to the review. ${ }^{114}$

There also appears to be considerable overlap between this provision and the variance provision in section 15.1 . For example, a person who is directly and adversely affected by a regional plan could apply for a review within the first year and if unsuccessful, try later for a variance. There is also some potential for overlap with a review provision in the original Act. Section 6 of the ALSA provides for a review of regional plans at least once every ten years by the Land-use Secretariat.

114 Ibid, s 19.2(4). These other procedural matters are set out in Part 1 of the ALSR, supra note 111. 
Like the variance provision, the review provision in the Amendments has the potential to lead to a multitude of requests for review. Again, this could have a chilling effect on regional plans. The temptation of those responsible for regional planning would likely be to remain with the status quo rather than risk a deluge of requests for review.

\section{F. IMPACT OF THE AMENDMENTS ON THE DISCRETIONARY Regional Planning Process}

The potential for uncertainty and misinterpretation created by the Amendments is compounded by the fact that the highly discretionary regional planning process of the original Act remains largely unchanged. The Cabinet, as a political decision-making body with few constraints on its decisions, raises the spectre of a lack of openness and transparency with respect to regional plans. Add to this the ambiguity and uncertainty created by many of the amendments, and the potential for inconsistent and unprincipled decisions increases.

The Amendments do little to address the highly discretionary regional planning process in the Act. In this regard, the most significant change is a repeal of section 5 which provided that Cabinet could amend or repeal a regional plan irrespective of any advice from the Landuse Secretariat or RAC. ${ }^{115}$ In its place, the new section 5 requires the Stewardship Minister to ensure that there has been "appropriate public consultation" with respect to the proposed regional plan and to "lay" the regional plan before the Legislative Assembly. Although the addition of a requirement for "appropriate public consultation" is a move towards greater transparency, the Cabinet still has the discretion to determine what form and amount of consultation would be appropriate for a regional plan. The significance of the requirement that a regional plan be laid before the Legislative Assembly is unclear. If a regional plan is to be reviewed by Legislature then this may add some greater transparency to the process. If, however, this provision simply means a regional plan is merely to be tabled with Legislature then it does not appear to add much benefit.

Elsewhere, the Amendments make changes that have the potential to allow the Minister greater political control by issuing directives that the Land-use Secretariat and the Stewardship Commissioner must following in carrying out their duties. ${ }^{116}$ Further, the Amendments also would extend the non-mandatory elements of a regional plan. ${ }^{117}$

\section{THE WAY FORWARD}

As the foregoing discussion demonstrates, ambiguities in the Amendments concerning respect for property rights and compensation, coupled with the addition of new challenge procedures that can be accessed by the landowner, and exacerbated by a highly discretionary regional planning process under the $A L S A$, the amended Act has the potential to undermine the purpose of the $L U F$ by creating greater uncertainty, weak regional plans, and a chill on

Ibid, s 5.

Ibid, s 17.1 .

Ibid. The Amendments add sections (h)-(m) to the list of elements that a regional plan may contain under s 8(2). 
regional planning. What, then, is needed to ensure that the $A L S A$, as amended, will support and implement the LUF?

First, the government must recognize that the landowner concerns about the Act are ideologically motivated, rather than legally well-founded. The LUF and the ALSA are generally consistent with a modern liberal approach to property rights, whereas many of the landowner concerns are reflective of a classical liberal perspective.

Second, the government should understand the significant differences in the values underlying the two different approaches to property rights — classical and modern. It should be apparent that in addition to creating ambiguity, the Amendments do not address or bridge the fundamental differences in how opposing sides view private property and the role of government.

Third, as the ALSA is intended to implement the $L U F$, it should be clear that only those amendments that clarify the interpretation of the ALSA and further the implementation of the purpose and values underlying the LUF should be retained. Accordingly, the additional reference to respect for private property rights in the purposes section and the compensation provision in section 19.1 should be clarified. Inclusion of these provisions creates uncertainty as to the appropriate balance between private property rights and the public interest. The refinements to the definition of "statutory consent" and section 11 could be retained, as they end any debate that land title was ever to be included as a statutory consent, but they are not necessary. The new variance and review provisions should be examined in light of the existing review provision in the $A L S A$. Viewed together, the available review and variance processes should be streamlined so that there is less overlap and the threshold, consequences, and procedure should be made clear.

Finally, the government should not lose sight of the purpose of the LUF and the importance that it should be implemented by legislation that will ensure more principled decisions and bring greater transparency to the regional planning process. Accordingly, the ALSA should be amended to make the regional planning process less discretionary. ${ }^{118}$ Regional planning should be required and the content of the regional plans more defined. As well, the government should not be trying to eliminate judicial scrutiny of these decisions.

\section{ConClusion}

The purpose of the LUF is to ensure the future economic growth of the province, balanced with the achievement of societal and environmental goals. The LUF can be understood as reflecting a modern liberal approach to land use planning such that government regulation is applied to all property, whether publically or privately owned. The ALSA was originally intended to implement the $L U F$ and to achieve its purpose. Objections to the ALSA based upon its perceived attack on the value and role of property rights resulted in the Amendments. The purported legal objections of opponents of ALSA, when examined, are ideological in nature, based upon a different understanding of private property rights rooted in classical liberalism. Some of the key provisions in the Amendments are ambiguous and 
could be interpreted differently from either a modern liberal or a classical liberal perspective. The result is an amended ALSA which could be interpreted so as to undermine the purpose of the $L U F$ and result in more land use planning controversy. If the goal of the legislation is to implement the LUF, then any amendments to the ALSA should be unambiguously consistent with the underlying values in the $L U F$ and should include the creation of more transparent and democratic procedures to implement that policy. 